Teologia i Moralność, volumen 12(2017), numer 2(22)

doi: 10.14746/tim.2017.22.2.7

\author{
BOŻENA BASSA \\ Uniwersytet Kardynała Stefana Wyszyńskiego w Warszawie \\ Wydział Studiów nad Rodziną
}

\title{
Troska o zdrowie prokreacyjne w naprotechnologii - formą budowania nowej kultury życia ludzkiego
}

Na przestrzeni wieków medycyna jako sztuka leczenia, oparta na zasadach hipokratejskich, uznawała obiektywną wartość każdego życia ludzkiego od momentu poczęcia aż do naturalnej śmierci. Zobowiązywała się także do szacunku dla osoby ludzkiej oraz ochrony jej życia i godności. Podstawę tego typu praktyki medycznej stanowiła zachęta do życia zgodnego z naturą, a w przypadku zaburzeń - przywracanie zdrowia, czyli integralności organizmu. Zadaniem medycyny było wspieranie ,wydobywania” sił wewnętrznych organizmu, wspomaganie jego naturalnych zdolności do przywrócenia równowagi życia ${ }^{1}$.

Taki sposób rozwiązywania problemów medycznych uległ radykalnej zmianie na skutek rozwoju nowych technik medycznych i specjalistycznej wiedzy medycznej. Postęp w tym zakresie rozszerza możliwości czynienia dobra poprzez diagnozowanie oraz leczenie wielu chorób. Jednocześnie bywa wykorzystywany do działań medycznych, które zamiast służenia zdrowiu i życiu ludzkiemu przekształcają się w rynek usług medycznych, zaprzeczających hipokratejskiemu charakterowi zawodu lekarza. Jednym z przełomowych wydarzeń w historii medycyny jest rozwój tak zwanej medycyny reprodukcyjnej²

1 Por. S. Warzeszak, Medycyno skąd i dokad idziesz? Filozoficzne tho rozwoju medycyny, w: Ustyszeć krzyk życia, red. M. Szumowski, Warszawa 2009, s. 18-19.

2 Obecnie medycyna reprodukcyjna staje się podstawowym narzędziem cywilizacji śmierci. Jan Paweł II napisał: „Medycyna, która z tytułu swego powołania ma służyć obronie życia ludzkiego i opiece nad nim, w niektórych dziedzinach staje się coraz częściej narzędziem czynów wymierzonych przeciw człowiekowi i tym samym zniekształca swoje oblicze, zaprzecza samej sobie i uwłacza godności tych, którzy ją uprawiają" - tenże, Encyklika Evangelium vitae, Wrocław 1995, n. 4. 
Nastąpił on na bazie kryzysu prokreacji związanego z rewolucją seksualną, która stanowiła „zaprogramowaną próbę oddzielenia sfery seksualnej od instytucji małżeństwa i perspektywy ojcostwa i macierzyństwa"3. Proponowane przez medycynę reprodukcyjną rozwiązania często usiłują zawłaszczyć ludzką płodność. Przejawia się to nie tylko w opanowaniu zdolności prokreacyjnych człowieka poprzez stosowanie środków antykoncepcyjnych i aborcji, ale także $\mathrm{w}$ radykalnym opanowaniu procesu prokreacyjnego poprzez zastosowanie technologii procedur rozrodczych. Prowadzi to do zastąpienia ludzkich zdolności rozrodczych technologiami reprodukcyjnymi, do podporządkowania ich biotechnologii oraz odpersonalizowania ${ }^{4}$. Medycyna reprodukcyjna nie jest ukierunkowana na wnikliwe rozpoznanie przyczyn warunkujących schorzenia ani na ich leczenie. Jej dominujący kierunek to podejście polegające na zatrzymaniu lub zaburzeniu płodności ${ }^{5}$. Promowane przez nią ingerencje w sferę ludzkiej prokreacji destrukcyjnie wpływają na rodzinę, generują liczne patologie oraz prowadzą do zaciemnienia sensu daru życia. Dlatego istnieje potrzeba rozwoju praktyk medycznych, które byłyby otwarte na najgłębszy osobowy i transcendentny wymiar człowieka oraz potrafiłyby przyjąć życie ludzkie jako dar ${ }^{6}$. Jedną z takich praktyk, opartych na tradycji hipokratejskiej, jest naprotechnologia, będąca dziedziną medycyny, specjalizującą się we wspomaganiu ludzkiej prokreacji oraz postrzegającą płodność i życie ludzkie w ścisłej relacji do powołania człowieka oraz zamysłu Stwórcy ${ }^{7}$.

\section{Walor edukacyjny naprotechnologii}

Podstawę, a zarazem integralną część naprotechnologii stanowi system nauczania określany jako Creighton Model Fertility Care System (CrMS, Model Creighton). Jest on elementem systemu opieki nad ludzką płodnością, stworzonym przez dr Thomasa Hilgersa wraz z zespołem współpracowni-

${ }^{3}$ L. Melina, Kurs bioetyki, Kraków 2016, s. 91.

${ }^{4}$ Por. S. Warzeszak, Ochrona funkcji prokreacyjnych malżeństwa $w$ świetle encykliki „Evangelium vitae" Jana Pawła II, w: Evangelium vitae - most ku przyszłości, red. J. Brusiło, A. Świerczek, Kraków 2011, s. 82.

${ }^{5}$ Obecnie pigułka hormonalna jest podstawowym środkiem „leczniczym” na wiele schorzeń ginekologicznych, zalecanym w rekomendacjach Towarzystw Ginekologicznych, na czele których stoją uznane autorytety medyczne. Doktor Hilgers wskazuje na ogromną liczbę kobiet, które doświadczyły na sobie skutków nieodpowiedniej diagnostyki i leczenia za pomocą tych środków „leczniczych” (por. T. Hilgers, The NaProTECHNOLOGY Revolution, Omaha 2010, s. XIX).

${ }^{6}$ Por. S. Warzeszak, Medycyno skad i dokad idziesz? Filozoficzne to rozwoju medycyny, dz. cyt., s. 10.

${ }^{7}$ Naprotechnologia zrodziła się z inspiracji katolickiej. Jest ona odpowiedzią na apel papieża Pawła VI z 27 n. encykliki Humanae vitae skierowany do lekarzy i służby medycznej. 
ków. Jego celem jest pomoc kobietom w zdobywaniu umiejętności wsłuchiwania się w ,autentyczny język zdrowia i płodności”. System ten opiera się na znajomości fizjologii płodności kobiety, uwarunkowanej cyklicznym wydzielaniem neurohormonu podwzgórza, gonadoliberyny (GnRH), który oddziałując na przysadkę mózgową, uwalnia w niej gonadotropiny - folitropinę (FSH) oraz lutotropinę (LH). Zmienne stężenia tych hormonów warunkują cykliczne przemiany w jajniku, takie jak rozwój i dojrzewanie pęcherzyków jajnikowych, owulacja oraz rozwój i zanik ciałka żółtego. Towarzyszące tym przemianom wydzielanie hormonów jajnikowych, estrogenów i progesteronu, wywiera efekty tkankowe, pozwalające na ustalenie kryteriów służących do wyróżnienia poszczególnych faz cyklu.

Najbardziej istotnym wskaźnikiem płodności jest wytwarzana pod wpływem hormonów jajnikowych w szyjce macicy wydzielina śluzowa, różniąca się jakością i ilością w zależności od fazy cyklu9. Monitorowanie jej cyklicznych zmian stanowi podstawę obserwacji dokonywanych w ramach CrMS. Umiejętności obserwacji i zapisu biologicznych biomarkerów, umożliwiających rozpoznawanie i rozumienie naturalnie występującego w cyklu kobiecym czasu płodności i niepłodności, małżonkowie uczą się pod kierunkiem instruktora troski o płodność ${ }^{10}$. Regularność prowadzenia obserwacji pozwala zaobserwować wydzielinę śluzową zawsze, kiedykolwiek się pojawi. Jest to fundamentalna zasada właściwego wykonywania i interpretowania obserwa$\mathrm{cji}^{11}$. Oprócz śluzu szyjkowego w CrMS monitorowaniu podlegają także m.in. rodzaje krwawień - przebieg miesiączki, plamienie przedmiesiączkowe oraz brązowe lub czarne plamienie kończące menstruację, a także długość cyklu

${ }^{8}$ Por. Z. Szymański, Endokrynologiczne uwarunkowania płodności kobiety, w: Płodność i planowanie rodziny, red. Z. Szymański, Szczecin 2004, s. 50. Do najważniejszych zmian, pojawiających się cyklicznie pod wpływem tych hormonów, należą: wydzielanie śluzu szyjkowego, zmiany położenia i konsystencji szyjki macicy oraz zmiany podstawowej temperatury ciała. Stanowią one zespół tak zwanych głównych objawów płodności. Zmiany te pojawiają się u każdej kobiety w okresie prokreacyjnym i mogą być łatwo przez nie zaobserwowane.

${ }^{9}$ Wraz ze wzrostem poziomu estrogenów w krwi, a tym samym wraz ze zbliżającą się owulacją, ilość śluzu zwiększa się, staje się on rozciągliwy, przezroczysty, dający odczucie lubrykacji. Śluz o takich cechach określany jest jako śluz typu Peak. Powstanie ciałka żółtego i wydzielanie progesteronu skutkuje pojawieniem się śluzu typu non Peak lub suchości (por. T. Hilgers, The Creighton Model Fertility Care ${ }^{T M}$ System. Basic Teaching Skills, Omaha 2002, s. 47-48).

${ }^{10}$ System opieki nad płodnością według CrMS zbudowany jest na koncepcji prowadzenia pary (case management). Instruktor uczy zasad prowadzenia obserwacji i zapisu biomarkerów. Pomaga użytkownikom zrozumieć podstawowe zasady rozpoznawania czasu płodności i niepłodności oraz znaczenia różnych wskaźników CrMS w odniesieniu do ich zdrowia prokreacyjnego. Standaryzacja systemu nauczania zapewnia wysoką jakość przekazu oraz równy dostęp do wiedzy wszystkich użytkowników. Proces nauczania obejmuje spotkanie wprowadzające i osiem spotkań w ciągu roku.

11 Por. T. Hilgers, Creighton Model Fertility Care ${ }^{T M}$ System. Autentyczny język zdrowia i płodności kobiety, Warszawa 2015, s. 13. Śluz stwarza środowisko sprzyjające plemnikom. Jest więc on naturalnym i niezbędnym elementem wspomagającym poczęcie dziecka. 
miesiączkowego, długość poszczególnych faz cyklu, występowanie dnia Peak. Pozwala to kobietom skutecznie wsłuchiwać się w mowę ciała i zdobywać informacje o przebiegu cyklu. Prawidłowo i rzetelnie wykonywane obserwacje zgodnie z regułami stosowanymi w CrMS oraz prawidłowe zapisywanie biomarkerów jest ważne dla skutecznego stosowania systemu. Prawidłowe obserwacje powinny być prowadzone niezależnie od intencji stosowania metody ${ }^{12}$. Ważnym elementem edukacji w CrMS jest poznanie podstawowych definicji, szczególnie: definicji śluzu typu Peak oraz śluzu typu non Peak, dnia Peak, a także fazy pre-Peak oraz post-Peak ${ }^{13}$.

Obserwacje według CrMS mogą być prowadzone przez każdą kobietę, na każdym etapie życia prokreacyjnego, począwszy od okresu dojrzewania. Wiedza o cyklicznej płodności kobiety, umożliwiająca poznanie i zrozumienie faz płodności i niepłodności występujących w cyklu menstruacyjnym, może być wykorzystana w planowaniu rodziny, opartym na „rozpoznaniu, akceptacji i respektowaniu biologicznego rytmu płodności, wpisanego w kobiecy cykl"14. Umiejętność rozpoznania czasu płodności i niepłodności umożliwia małżonkom podejmowanie właściwych decyzji rodzicielskich. Z CrMS mogą korzystać zarówno w celu uzyskania poczęcia, jak i jego odkładania, natomiast system nigdy nie może być traktowany jako środek antykoncepcyjny ${ }^{15}$. Dla właściwego stosowania CrMS w różnych sytuacjach życiowych istotne jest zrozumienie i przestrzeganie podstawowych instrukcji. Dotyczą one precyzyjnego określania dni płodności i niepłodności, w zależności od przynależności pary do danej kategorii prokreacyjnej oraz stopnia zaawansowania w poznaniu metody ${ }^{16}$. Ponieważ CrMS dostosowany jest do każdej pary, dlatego małżonkowie, którzy znajdują się w sytuacjach szczególnych, powinni zapoznać się z instrukcjami dodatkowymi. Dotyczy to m.in. czasu karmienia piersią, sytuacji po odstawieniu antykoncepcji hormonalnej, okresu menopauzy czy problemów z poczęciem dziecka ${ }^{17}$.

$\mathrm{Z}$ codziennych obserwacji biomarkerów zgodnie z zasadami CrMS mogą korzystać kobiety w różnych sytuacjach życiowych - mające regularne bądź nieregularne cykle, rezygnujące $\mathrm{z}$ dalszego stosowania antykoncepcji hormo-

12 Por. tamże, s. 29-30.

${ }^{13}$ Por. tamże, s. 23.

${ }^{14}$ W. Fijałkowski, Ekologia rodziny, Kraków 2001, s. 27. Śluz fazy pre-peak jest estrogenozależny. Występuje wtedy, gdy stężenie estrogenów we krwi jest na odpowiednio wysokim poziomie. Natomiast wysokim poziomom progesteronu odpowiada suchość lub obecność śluzu charakterystycznego dla tej fazy cyklu

${ }^{15}$ Por. T. Hilgers, Creighton Model Fertility Care ${ }^{T M}$ System. Autentyczny język zdrowia i płodności kobiety, dz. cyt., s. 1.

${ }^{16}$ Szczegółowe omówienie podstawowych instrukcji znajduje się w: T. Hilgers, The Creighton Model Fertility Care ${ }^{T M}$ System. Basic Teaching Skills, dz. cyt., s. 106-113.

${ }^{17}$ Por. tamże, s. 119-130. 
nalnej, karmiące piersią, a także kobiety, u których występują długie cykle śluzowe, cykle suche, cykle bezowulacyjne ${ }^{18}$.

W przeciwieństwie do antykoncepcji, CrMS traktuje płodność jako normalny proces zdrowotny, a nie jak chorobę, którą trzeba wyeliminować. Uczy żyć z nią w harmonii. Dostarcza małżonkom informacji o czasie ich płodności i niepłodności, ale decyzję o podjęciu współżycia lub jego odłożeniu podejmują oni sami, zgodnie z intencją uzyskania lub odłożenia poczęcia. Dokładność rozpoznania czasu płodności sprawia, że użytkownicy CrMS z prawidłową płodnością, wykorzystując na współżycie małżeńskie dni płodne, uzyskują poczęcie dziecka w pierwszym cyklu aż w $76 \%$, w drugim cyklu w $90 \%$ oraz w szóstym cyklu w $98 \%{ }^{19}$. System ten pomaga także małżonkom, którzy cierpią z powodu niepłodności, w próbach uzyskania poczęcia.

Zdobyta wiedza na temat płodności pozwala docenić, jak wielkim jest ona darem. Małżonkowie, którzy znają swoją płodność oraz w sytuacji odkładania poczęcia, unikają kontaktu genitalnego w okresie płodnym, mają możliwość rozwijania innych, niegenitalnych sposobów wyrażania swojej relacji seksualnej, co sprzyja rozwojowi miłości, współdziałaniu i zaangażowaniu służącemu pogłębieniu więzi małżeńskiej ${ }^{20}$.

Model Creighton stanowi cenną propozycję dla współczesnych małżonków, których wiedza na temat fizjologicznych zmian zachodzących w cyklu, możliwości ich monitorowania oraz wykorzystania tej wiedzy w realizacji rodzicielstwa często jest bardzo ograniczona lub nieprawdziwa. Ten brak adekwatnej wiedzy sprawia, że chętnie korzystają z łatwo dostępnych środków antykoncepcyjnych.

\section{Walor diagnostyczno-terapeutyczny naprotechnologii}

Prowadzone w ramach CrMS monitorowanie biomarkerów płodności daje wgląd w zdrowie kobiety, pozwalając rozpoznać komunikaty płynące ze strony jej organizmu ${ }^{21}$. Dlatego jest bardzo przydatny w ocenie zdrowia ginekologicznego. Znajomość podstawowych wskaźników płodności oraz ich codzienne monitorowanie pozwala z dużą dokładnością wskazać czas owulacji, rozwój objawu śluzu szyjkowego oraz prawidłowość fazy poowulacyjnej. Może służyć także jako cenny, niekiedy pierwszy sygnał zaburzeń zdrowia ginekologicznego, takich jak: brak owulacji najczęściej spowodowany zabu-

${ }^{18}$ Por. tamże, s. 5

${ }^{19}$ Por. tamże, s. 223-224.

${ }^{20}$ Por. T. Hilgers, Creighton Model Fertility Care ${ }^{T M}$ System. Autentyczny język zdrowia i płodności kobiety, dz. cyt., s. Xi.

${ }^{21}$ Por. tamże, s. 1. 
rzeniami czynności układu podwzgórze - przysadka - jajniki czy stale skrócona faza lutealna, świadcząca o niewydolności ciałka żółtego. Na niewydolność ciałka żółtego dodatkowo będą wskazywały plamienia przedmiesiączkowe, zespół napięcia przedmiesiączkowego, nawykowe wczesne poronienia ${ }^{22}$.

Stosowanie CrMS pozwala zaobserwować także nieprawidłowości krwawień miesiączkowych. Zaburzenia te mogą być związane z obfitością krwawień (krwawieniami skąpymi i krótkotrwałymi, nadmiernie obfitymi, a także nadmiernie obfitymi i przedłużonymi) albo ich częstotliwością (pierwotnym lub wtórnym brakiem miesiączek). W cyklu mogą występować także krwawienia poza terminem prawidłowej miesiączki. Ich przyczyną mogą być zaburzenia organiczne lub hormonalne, wymagające wnikliwej diagnostyki i leczenia. Monitorowanie cyklu pozwala ustalić charakter krwawień, co ma duże znaczenie w okresach szczególnych w życiu kobiety, takich jak zagrażające poronienie, okres poporodowy czy premenopauza ${ }^{23}$. Inne schorzenia, które moga łatwo być zidentyfikowane przy okazji prowadzenia obserwacji wskaźników płodności, to stany zapalne pochwy i szyjki macicy. Przebiegają one pod postacią upławów połączonych z pieczeniem i bolesnością. Rodzaj upławów będzie stanowił informację o rodzaju zakażenia ${ }^{24}$.

System monitorowania wskaźników płodności pozwala zidentyfikować charakter torbieli jajnikowych, co w wielu przypadkach prowadzi do mniejszej potrzeby interwencji chirurgicznej. Kobiety, u których wykryto torbiele funkcjonalne, nie są poddawane zabiegom chirurgicznym. W tradycyjnym leczeniu ginekologicznym u wielu kobiet, szczególnie młodych, w związku ze zdiagnozowaniem torbieli przeprowadza się operacje wtedy, kiedy nie są one potrzebne. Skutkiem ubocznym takich operacji jest tworzenie się blizn, które mogą być przyczyną niepłodności ${ }^{25}$.

Model Creighton ma szczególne zastosowanie w stanach obniżonej płodności lub niepłodności. Celem samoobserwacji w tych sytuacjach będzie rozpoznanie okresu najwyższej płodności w cyklu miesiączkowym kobiety oraz celowane współżycie, a także wybór optymalnego czasu na wykonanie badań oraz na wdrożenie leczenia i jego monitorowanie.

Prowadzenie obserwacji zgodnie z CrMS pozwala zastosować celowaną ocenę hormonalną cyklu miesiączkowego oraz jest pomocne w ustaleniu wła-

${ }^{22}$ Por. M. Szczawińska, Zakłócenia samoobserwacji oraz zaburzenia cykli miesiączkowych kobiety, w: Ptodność i planowanie rodziny, dz. cyt., s. 87-89.

${ }^{23}$ Por. tamże, s. 89-91.

${ }^{24} \mathrm{Na}$ przykład w zakażeniu grzybiczym upławy będą białawe, serowate, gęste, powodujące pieczenie, świąd i ból. Pieniste zielonkawe upławy będą towarzyszyły zakażeniu rzęsistkiem pochwowym. Wodnista, obfita czasami żółtawa wydzielina może towarzyszyć zakażeniom bakteryjnym (por. T. Hilgers, Reproductive Anatomy and Physiology, Omaha 2002, s. 151-152).

${ }^{25}$ Por. T. Hilgers, Creighton Model Fertility Care ${ }^{T M}$ System. Autentyczny język zdrowia i płodności kobiety, dz. cyt., s. 44-45. 
ściwych dni wykonania poszczególnych badañ ${ }^{26}$. I tak histerosalpingografia jest wykonywana pomiędzy 4 a 8 lub 10 dniem cyklu. W tej procedurze w światło jajowodów wprowadzany jest barwnik, a w przypadku niedrożności jajowody są udrażniane różnymi metodami. Biopsję endometrium wykonuje się dzień lub dwa dni przed rozpoczęciem menstruacji. Badanie to polega na pobraniu fragmentu tkanki, a następnie określeniu pod mikroskopem obecności lub braku zaburzeń, będących odpowiedzią ze strony endometrium na działanie hormonów jajnikowych ${ }^{27}$.

W przedowulacyjnej fazie cyklu wykonuje się diagnostyczną laparoskopię. Badanie to pozwala obserwować organy wewnętrzne w kierunku obecności lub braku procesów chorobowych, mogących powodować niepłodność. Umożliwia identyfikację takich schorzeń, jak: nieprawidłowości anatomiczne, endometrioza, policystyczne jajniki, zrosty. W czasie laparoskopii przeprowadza się także test drożności jajowodów. Przez szyjkę macicy wprowadza się barwnik, który przy właściwej drożności jajowodów swobodnie przez nie przechodzi. Dokładniejszy obraz patologicznych zmian jest rezultatem wykonywanej w naprotechnologii tak zwanej near contact laparoskopy - laparoskopii bliskiego kontaktu ${ }^{28}$.

W celu oceny owulacji lub występowania jej defektów wykonuje się serię badań ultrasonograficznych, pozwalających śledzić rozwój pęcherzyka jajnikowego, proces owulacji i jego ewentualne zaburzenia, takie jak: niepęknięty pęcherzyk jajnikowy, pęcherzyk niedojrzały lub pusty ${ }^{29}$.

Podstawową zasadę interpretacji zaburzeń stanowi celowana ocena hormonalna cyklu poprzez wykonanie profilu hormonalnego zintegrowanego z obserwacją owulacyjnego typu śluzu szyjkowego i funkcjonowania ciałka żółtego ${ }^{30}$.

Przeprowadzone badania dają możliwość rozpoznania wielu zaburzeń i ich przyczyn, m.in.: stanów zapalnych szyjki macicy, nadżerki szyjki macicy, różnego typu cyst jajnikowych, zaburzeń funkcjonowania jajników, nieprawidłowych krwawień, mięśniaków macicy, endometriozy, zaburzeń folikulogenezy i luteogenezy, zaburzeń funkcji tarczycy, zaburzeń podwzgórzowych, przysadkowych i jajnikowych, choroby zrostowej w miednicy mniejszej, braku

${ }^{26}$ Por. tamże, s. 43.

27 Por. T. Hilgers, Reproductive Anatomy and Physiology, dz. cyt., s. 161-164.

28 Por. tamże, s. 168; por. T. Hilgers, The NaProTECHNOLOGY Revolution, dz. cyt., s. 161.

29 Por. T. Hilgers, Reproductive Anatomy and Physiology, dz. cyt., s. 166.

30 Pełny profil hormonalny obejmuje: dzień 5: FSH, beta endorfiny; P-5 do P+2 co drugi dzień $\mathrm{E} 2 ; \mathrm{P}+3,5,7,9,11: \mathrm{P}+\mathrm{E} 2 ; \mathrm{P}+5,7$, 9: beta endorfiny; $\mathrm{P}+7$ : testosteron, wolny testosteron, DHEAs; FSH, LH, PRL, całkowity T4, wolny T4, TSH, całkowity T3, reverse T3, T3 i rT3 ratio (por. T. Hilgers, The Medical and Surgical practice of NaProTECHNOLOGY, Omaha 2004, s. 517). 
miesiączki czy braku owulacji ${ }^{31}$. Wiele tych zaburzeń może powodować niepłodność.

Naprotechnologia diagnozuje także niepłodność mężczyzny. Duże znaczenie diagnostyczne ma test po stosunku, zwany testem postkoitalnym, określający przeżywalność i zachowanie plemników w śluzie szyjkowym kobiety. Test ten wykonuje się w okresie okołoowulacyjnym, właściwie rozpoznanym na podstawie obserwacji prowadzonych $\mathrm{w}$ ramach $\mathrm{CrMS}^{32}$. Przeprowadza się także badanie parametrów i morfologii nasienia. Sposób wykonywania badania respektuje godność aktu małżeńskiego i nie zakłada pobrania nasienia przez masturbację. Pobiera się je po normalnym akcie małżeńskim przy użyciu seminal collection device, zbiorniczka umożliwiającego takie pobranie. Wyniki badań naukowych potwierdzają wyższą wartość diagnostyczną nasienia pobranego w sposób naturalny w stosunku do pobrań za pomocą masturbacji ${ }^{33}$.

Umiejętność monitorowania cyklu na podstawie CrMS ma zastosowanie także w ukierunkowanym leczeniu. Przykładem tego jest współpracująca progesteronowa terapia zastępcza (Cooperative Prgesterone Replacement Therapy - CPRT) oraz współpracująca estrogenowa terapia zastępcza (Cooperative Estrogene Replacement Therapy - CERT). We współczesnej ginekologii terapia progesteronowa stosowana jest konkretnego dnia w każdym cyklu. Taki sposób postępowania jest nieprawidłowy ze względu na zmienną długość fazy przedowulacyjnej cyklu ${ }^{34}$. W naprotechnologii natomiast wyznaczony dzięki prowadzonym obserwacjom w ramach CrMS dzień Peak jako wiarygodny objaw owulacji stanowi punkt odniesienia do prawidłowej aplikacji terapii progesteronowej. Tylko takie aplikowanie progesteronu $\mathrm{w}$ fazie poowulacyjnej będzie miało znaczenie terapeutyczne. Korzyścią zastosowania tej terapii jest także regulacja cykli miesiączkowych ${ }^{35}$. W naprotechnologii wykorzystane są hormony izomolecularne, które pod względem biologicznym i fizjologicznym są takie same jak hormony produkowane w ludzkim organizmie i dlatego są bezpieczne. Oczywiście, leczenie z zastosowaniem tych hormonów powinno być poprzedzone wnikliwą oceną hormonalną cyklu ${ }^{36}$.

${ }^{31}$ Por. T. Hilgers, Creighton Model Fertility Care ${ }^{T M}$ System. Autentyczny język zdrowia i płodności kobiety, dz. cyt., s. 44-47.

${ }^{32}$ Por. T. Hilgers, Reproductive Anatomy and Physiology, dz. cyt., s. 167.

${ }^{33}$ Por. tamże; por. M. Barczentewicz, Naprotechnology jako narzędzie do diagnostyki i leczenia niepłodności i innych chorób, dz. cyt., s. 231.

${ }^{34}$ Owulacja ma miejsce w 14 . dniu cyklu tylko w $13,5 \%$ cykli. Progesteron podany w przedowulacyjnej fazie cyklu nie spełnia funkcji terapeutycznej, ale zaburza cykl.

${ }^{35}$ Por. T. Hilgers, The NaProTECHNOLOGY Revolution, dz. cyt., s. 106-111.

${ }^{36}$ Por. tamże, s. 131. W medycynie reprodukcyjnej powszechnie stosowane są tak zwane hormony heteromolekularne. Są to sztuczne substancje o działaniu progesteronopodobnym i estrogenopododnym, wywołujące szereg efektów ubocznych. 
Istotne miejsce w terapii zajmuje tak zwana Surgical NaProTECHNOLOGY. W przeciwieństwie do klasycznej chirurgii ginekologicznej szczególny nacisk położony jest $\mathrm{w}$ niej na cel, jakim jest przywrócenie naturalnej płodności organizmu. Surgical NaProTECHNOLOGY jest chirurgią plastyczną miednicy mniejszej, wymagającą od lekarzy doświadczenia w obsłudze laserów i w mikrochirurgii. Wykorzystywane są w niej techniki przeciwzrostowe: odpowiednie techniki cięcia, troska o homeostazę, prawidłowy dobór szwów, odpowiedni dobór narzędzi i przede wszystkim odpowiednia kultura operacyj$\mathrm{na}^{37}$. Za pomocą tych technik chirurgicznych przeprowadza się zabiegi rekonstrukcji narządów miednicy mniejszej.

Surgical NaProTECHNOLOGY pomaga m.in. w leczeniu zespołu policystycznych jajników oraz endometriozy. Zespół policystycznych jajników obecnie jest łatwo rozpoznawany, ale powszechnie nieprawidłowo leczony $\mathrm{z}$ zastosowaniem hormonalnych tabletek antykoncepcyjnych, co może doprowadzić do problemów z płodnością, a także powodować ryzyko wystąpienia chorób nowotworowych z powodu długotrwałego podawania estrogenów. Naprotechnologia jako rozwiązanie proponuje klinową laserową resekcję jajników. Tego typu leczenie chirurgiczne z uwzględnieniem technik przeciwzrostowych skutecznie przywraca fizjologiczne funkcje jajnika ${ }^{38}$. W leczeniu endometriozy w naprotechnologii zabiegi przeprowadzane są za pomocą technik laparoskopowych, zwłaszcza laparoskopu bliskiego kontaktu. Podczas zabiegów z wykorzystaniem nowoczesnych technik laserowych dokonuje się waporyzacji ognisk endometriozy oraz rekonstrukcji narządów rozrodczych.

Naprotechnologia ze względu na wnikliwą diagnozę, na podstawie której podejmuje się adekwatne, wielowymiarowe leczenie, charakteryzuje się wysoką skutecznością w leczeniu niepłodności. Skuteczność naprotechnologii dla małżeństw, które wcześniej bez oczekiwanego rezultatu starały się o dziecko, wynosi przeciętnie 40-60\%. Wskaźnik ten wzrasta w odniesieniu do małżeństw, które wcześniej doświadczały nawykowych poronień, spada natomiast do $20-30 \% \mathrm{w}$ przypadku par, które przeszły kilka nieudanych prób zapłodnienia in vitro. Wskaźnik poczęć po leczeniu z powodu niepłodności metodami naprotechnologii wynosi w zależności od czasu trwania leczenia odpowiednio: do 12 miesięcy - uzyskano 44\% ciąż, do 24 miesięcy

${ }^{37}$ Por. B. Bassa, Sprawozdanie z Międzynarodowej Konferencji szkoleniowo-naukowej „NaProTECHNOLOGY - nowa dziedzina poświęcona zdrowiu kobiety” - Lublin 12-13 września 2009 roku, „Studia nad Rodziną” 2009, nr 1-2, s. 365-366.

${ }^{38}$ Por. tamże, s. 366. Ten sposób leczenia w przeszłości stosowany był także w Polsce. Został zaniechany ze względu na rozległe zrosty pooperacyjne, będące skutkiem stosowania nieprawidłowych technik operacyjnych (por. tamże). 
- uzyskano $62 \%$ poczęć, do 48 miesięcy od rozpoczęcia leczenia - 71\% poczęćc c $^{39}$.

W niektórych grupach chorych skuteczność jest wyższa - sięga nawet $80 \%$ zależnie od przyczyny, wieku, diagnostyki i stosowanego wcześniej leczenia. Naprotechnologia ma także zastosowanie terapeutyczne w przypadku niepłodności męskiej. Na przykład u pacjentów z oligospermią (mała liczba plemników w nasieniu) podstawowym leczeniem jest stosowanie Clomiphenu, który u 55\% pacjentów prowadzi do poprawy parametrów nasienia. Natomiast pacjentom z obniżoną ruchliwością plemników aplikuje się z powodzeniem iniekcje z gonadotropiny kosmówkowej (HCG). W leczeniu męskiej niepłodności wykorzystuje się także suplementację minerałów i witamin, na przykład witaminy $\mathrm{E}^{40}$.

Nowa wiedza o zdrowiu prokreacyjnym, jaką jest naprotechnologia, opiera się na współpracy $\mathrm{z}$ cyklem płodności w odnalezieniu powodujących dane symptomy przyczyn i leczeniu zmierzającym do wyeliminowania ich. Proponuje także nowe podejście do pacjentów przez słuchanie oraz podmiotowe odnoszenie się do nich.

\section{Naprotechnologia - nowa nauka medyczna w służbie osoby ludzkiej i godności przekazywania życia ${ }^{41}$}

Naprotechnologia poprzez kształtowanie nowego oblicza medycyny i służby medycznej przyczynia się do budowania cywilizacji miłości i życia. Istotnym elementem cywilizacji życia, realizowanym przez tę naukę, jest afirmatywna postawa lekarza wobec przekazywania życia i jego godności w małżeństwie ${ }^{42}$.

Naprotechnologia stoi na straży ludzkiej prokreacji rozumianej jako współudział małżonków w akcie stwórczym Boga, który jest Panem i dawcą życia. Świadomość współpracy z Bogiem pozwala widzieć każde zrodzone dziecko w egzystencjalnym związku zarówno z Bogiem, jak i z rodzicami, którzy przyjmują to nowe życie jako dar ${ }^{43}$. Szanuje podstawową zasadę, że poczęcie ludzkiego życia związane jest wyłącznie z aktem miłości małżeńskiej, w którego strukturę wpisana jest taka możliwość. Dlatego uznaje podstawową za-

${ }^{39}$ Por. M. Barczentewicz, NaProTECHNOLOGY nowa wizja NPR w Polsce. Diagnostyka i leczenie niepłodności, „Życie i Płodność” 2009, nr 2, s. 88.

${ }^{40}$ Por. T. Hilgers, The NaProTECHNOLOGY Revolution, dz. cyt., s. 308-309.

${ }^{41}$ Por. tamże, s. 34.

${ }^{42}$ Por. P. Marzec, Naprotechnologia. Nowoczesna troska o płodność, Tarnów 2015, s. 199-200.

${ }^{43}$ Por. S. Warzeszak, Ochrona funkcji prokreacyjnych matżeństwa w świetle encykliki Evangelium vitae Jana Pawła II, dz. cyt., s. 94-95. 
sadę, że każdy akt zjednoczenia małżeńskiego powinien być otwarty na dar ludzkiego życia ${ }^{44}$.

Naprotechnologia docenia znaczenie troski o dojrzałą więź małżeńską, na której buduje się wspólnota miłości i życia, obejmująca wszystkie wymiary człowieczeństwa $^{45}$. Zrozumienie i docenienie płodności pozwala parom na pogłębienie ich relacji małżeńskich. Małżonkowie dokładnie wiedzą, kiedy są płodni, a kiedy niepłodni. Ta świadomość pozwala im podejmować akty autentycznie płodne i współpracować ze Stwórcą w powoływaniu nowego ludzkiego życia. Dla małżonków stosujących CrMS decyzja dotycząca podjęcia kontaktu genitalnego $\mathrm{w}$ danym czasie lub zaniechania go związana jest $\mathrm{z}$ intencją uzyskiwania poczęcia lub odkładania go w czasie. Jeśli intencją małżonków jest odkładanie poczęcia w czasie i jest to czas płodny, warunkiem właściwego stosowania metody jest niepodejmowanie kontaktu genitalnego w tym okresie. Model Creighton ukierunkowuje małżonków na prowadzenie rozmów dotyczących intencji korzystania z metody, a nie tego, czy w danym czasie powinni podejmować współżycie ${ }^{46}$.

$\mathrm{Z}$ intencją odkładania poczęcia w czasie związana jest okresowa wstrzemięźliwość od kontaktu genitalnego, czyli fizycznego kontaktu narządów płciowych. Jednak w CrMS wstrzemięźliwość nie jest traktowana jako utrudnienie związane ze stosowaniem metody, ale jako możliwość pozwalająca małżonkom „umiejscowić we właściwej perspektywie całość ich ludzkiej seksualności oraz odkryć czynniki «głęboko ożywiające» płciowość»"47.

Unikając okresowo kontaktu genitalnego, małżonkowie zaproszeni są do wyrażania siebie i porozumiewania się za pomocą innych, niegenitalnych sposobów. Taki styl komunikacji sprzyja rozwojowi osobowości każdego z nich oraz budowaniu głębokich więzi, porozumienia i zaufania, stanowiących podstawę prawdziwej komunii osób, „która jest wyzwalająca, miłująca i trwała”48.

Naprotechnologia realizuje personalistyczną wizję medycyny, w której celem zabiegów leczniczych jest nie tylko zdrowie poszczególnych organów czy całego ciała, ale dobro całej osoby ludzkiej. Również zdolność przekazywania życia, choć wpisana w zdrowe ludzkie ciało, jest wartością dotyczącą całej osoby, realizującą się w rodzicielstwie. Dlatego naprotechnologia stosuje

${ }^{44}$ Por. Paweł VI, Encyklika Humanae vitae, Wrocław 1999, n. 12.

${ }^{45} \mathrm{~W}$ ramach prowadzenia pary za pomocą tak zwanego indeksu SPICE dokonuje się oceny istniejącej między małżonkami więzi. Ocena ta obejmuje poziom duchowy (spiritual S), cielesny (phisical $\mathrm{P}$ ), intelektualny (intelectual $\mathrm{I}$ ), kreatywno-komunikacyjny (creative-communicative, $\mathrm{C}$ ) oraz emocjonalny (emotional E) (por. T. Hilgers, Creighton Model Fertility Care ${ }^{T M}$ System. Autentyczny język zdrowia i płodności kobiety, dz. cyt., s. 36-37.

${ }^{46}$ Por. T. Hilgers, Creighton Model Fertility Care ${ }^{T M}$ System. Autentyczny język zdrowia i płodności kobiety, dz. cyt., s. 38-39.

${ }^{47}$ Por. tamże, s. 35.

${ }^{48}$ Por. tamże. 
dostępne środki i metody leczenia, które przywracają naturalną zdolność prokreacyjną, nie zastępując jej. W ten sposób włącza się w budowanie „,nowej kultury życia" ${ }^{49}$. Jednym $\mathrm{z}$ fundamentalnych wymiarów tej kultury jest troska o każde życie ludzkie, zwłaszcza to najsłabsze, która stanowi podstawową normę etyki lekarskiej i jest głównym zadaniem lekarza, rozciągającym się na całą jego praktykę. Lekarz opiekuje się zdrowiem, chroni życie ludzi, jest powiernikiem ich prywatnych spraw i osobistych tajemnic. Troska ta obejmuje w sposób szczególny zaangażowanie na rzecz życia dziecka w najwcześniejszym okresie jego rozwoju. Powinna być nią objęta również rodzina, w której dziecko przychodzi na świat ${ }^{50}$.

Naprotechnologia proponuje podejście do płodności leczące, wspomagające, wypływające z wizji medycyny, która szuka przyczyn zaburzeń i je eliminuje. Jan Paweł II wyraził uznanie dla dr. T Hilgersa i stworzonego przez niego dzieła w następujących słowach: ,Jestem wdzięczny za wkład Instytutu w promocję wiernego nauczania Kościoła o małżeństwie i rodzinie. W szczególny sposób chcę uznać i zachęcić do kontynuowania wysiłków Instytutu w budowaniu kultury życia, tak żywotnie ważnej w dzisiejszym społeczeństwie" $"$.

\section{CONCERN FOR THE PROCREATIVE HEALTH IN NAPROTECHNOLOGY - FORM OF BUILDING A NEW CULTURE OF HUMAN LIFE}

\section{Summary}

NaProTECHNOLOGY is a new field of medicine specializing in the promotion of human procreation. Its foundation is a teaching system called the Creighton Model Fertility Care System. It is based on the ability to observe and record biological biomarkers, enabling spouses to recognize and understand the naturally occurring cycle of fertility and infertility. The spouses can use their acquired knowledge both for achieving pregnancy and avoiding it. The system also enables them to broaden their knowledge to better understand sexuality and deepen their mutual love. It also plays

\footnotetext{
49 Jan Paweł II w Encyklice Evangelium vitae n. 95 wyjaśnia, że chodzi o kulturę „nową, to znaczy zdolną podejmować i rozwiązywać istniejące dziś, a dawniej nieznane problemy związane z ludzkim życiem; nową, to znaczy bardziej zdecydowanie i czynnie przyjętą przez wszystkich chrześcijan; nową, to znaczy zdolną pobudzić do poważnej i śmiałej konfrontacji kulturowej ze wszystkimi”.

${ }^{50}$ Por. B. Bassa, Medycyna w stużbie ludzkiego życia, w: Kościót rodzina życie, red. M. Ozorowski, A. Skreczko, Warszawa 2011, s. 136.

${ }^{51}$ Letter sent on the Tenth Anniversary of the Pope Paul VI Institute's Founding. "From the Vatican", cyt. za P. Marzec, Naprotechnologia. Nowoczesna troska o płodność, dz. cyt., s. 205.
} 
an important role in diagnosing and treating reproductive health according to the natural cycle of women. NaProTECHNOLOGY is involved in building a "new culture of life" through integral concern for human fertility by restoring natural procreation and respecting the principles of responsible parenthood.

Słowa kluczowe: rodzicielstwo; troska o płodność; zdrowie prokreacyjne; naprotechnologia; Creighton Model Fertility Care ${ }^{T M}$ System

Keywords: parenthood; care for fertility; proceative health; NaProTECHNOLOGY; Creighton Model Fertility Care ${ }^{T M}$ System

\section{BIBLIOGRAFIA}

Barczentewicz M., Naprotechnology jako narzędzie do diagnostyki i leczenia niepłodności i innych chorób, w: Naturalne planowanie rodziny w ujęciu wybranych dyscyplin naukowych, red. W. Wieczorek i in., Lublin 2008, s. 229-237.

Barczentewicz M., NaProTECHNOLOGY nowa wizja NPR w Polsce. Diagnostyka i leczenie niepłodności, „Życie i Płodność” 2009, nr 2, s. 83-91.

Bassa B., Sprawozdanie z Międzynarodowej Konferencji szkoleniowo-naukowej „NaProTECHNOLOGY - nowa dziedzina poświęcona zdrowiu kobiety" - Lublin 12-13 września 2009 roku, „Studia nad Rodziną” 2009, nr 1-2, s. 365-366.

Bassa B., Medycyna w stużbie ludzkiego życia, w: Kościól rodzina życie, red. M. Ozorowski, A. Skreczko, Warszawa 2011, s. 133-144.

Fijałkowski W., Ekologia rodziny, Kraków 2001.

Hilgers T., Creighton Model Fertility Care ${ }^{T M}$ System. Autentyczny język zdrowia i płodności kobiety, thum. E Marchlewska, Warszawa 2015.

Hilgers T., Reproductive Anatomy and Physiology, Omaha 2002.

Hilgers T., The Creighton Model Fertility Care ${ }^{T M}$ System. Advanced Teaching Skills, Omaha 2003.

Hilgers T., The Creighton Model Fertility Care ${ }^{T M}$ System. Basic Teaching Skills, Omaha 2002.

Hilgers T., The Medical and Surgical practice of NaProTECHNOLOGY, Omaha 2004.

Hilgers T., The NaProTECHNOLOGY Revolution, Omaha 2010.

Jan Paweł II, Encyklika Evangelium vitae, Wrocław 1995.

Marzec P., Naprotechnologia. Nowoczesna troska o plodność, Tarnów 2015.

Melina L., Kurs bioetyki, Kraków 2016.

Paweł VI, Encyklika Humanae vitae, Wrocław 1999.

Szczawińska M., Zakłócenia samoobserwacji oraz zaburzenia cykli miesiaczkowych kobiety, w: Płodność i planowanie rodziny, red. Z. Szymański, Szczecin 2004, s. 76-93.

Warzeszak S., Medycyno skąd i dokad idziesz?. Filozoficzne tło rozwoju medycyny, w: Ustyszeć krzyk życia, red. M. Szumowski, Warszawa 2009, s. 17-30.

Warzeszak S., Ochrona funkcji prokreacyjnych malżeństwa w świetle encykliki Evangelium vitae Jana Pawła II, w: Evangelium vitae - most ku przyszłości, red. J. Brusiło, A. Świerczek, Kraków 2011, s. 81-96.

BożenA BASSA - adiunkt w Katedrze Wychowania Zdrowotnego i Odpowiedzialnego Rodzicielstwa Wydziału Studiów nad Rodziną Uniwersytetu Kardynała Stefana Wyszyńskiego w Warszawie. Absolwentka Pope Paul VI Institute for the 
Study of Human Reproduction w Omaha, Nebraska. Praca naukowo-badawcza ukierunkowana jest na interdyscyplinarne zagadnienia związane z małżeństwem i rodziną, ze szczególnym uwzględnieniem problematyki odpowiedzialnego rodzicielstwa w aspekcie uwarunkowań biomedycznych, promocji zachowań prozdrowotnych, a także diagnozowania i leczenia zaburzeń zdrowia prokreacyjnego. Autorka publikacji naukowych w tym zakresie. Członek zarządu Polskiego Stowarzyszenia Familiologicznego oraz członek zarządu Fertility Care Centers of Poland. 